\title{
Mariano Croce \& Andrea Salvatore, The Legal Theory of Carl Schmitt
}

\author{
Michiel Besters
}

Mariano Croce \& Andrea Salvatore, The Legal Theory of Carl Schmitt (Abingdon: Routledge, 2013), $204 p$.

Although Carl Schmitt's legal scholarship has always been beyond discussion, it took some time after his engagement with the Nazi regime before he was judged afresh on his theoretical merits. This is not without reason. Schmitt not only took up the position as Kronjurist des Dritten Reiches, but the works published during the period of his Nazi engagement show evidence of his belief in the German Großraum, regardless if these were expressions of true belief or opportunistic gestures towards the new regime. Nevertheless, the fact that Schmitt's legal theory was not, and perhaps still is not and never will be, salonfähig did not stop scholars from reading his work. More than once, Schmitt functions as a named and unnamed discussion partner. Think for example of Jürgen Habermas' reflections on the nation-state and Hannah Arendt's analysis of nomos. In the last few decades, however, renewed scholarly attention to Schmitt's legal theory has resulted in some valuable publications and advanced the propagation of his key insights.

Traditional interpretations of Schmitt's legal theory devote much attention to publications before and after his Nazi engagement, notably Political Theology (1921) and Constitutional Theory (1928) and The Nomos of the Earth (1950). A new book by Mariano Croce and Andrea Salvatore entitled The Legal Theory of Carl Schmitt (Routledge, 2013) challenges these traditional interpretations. Their alternative interpretation hinges on a short essay published in 1934, On the Three Types of Juristic Thought, which is normally associated with Schmitt's dark period. Schmitt argues in this essay that concrete order (konkreten Ordnung), and not a norm or a decision, is the fundamental concept of legal theory. In a nutshell, Croce and Salvatore claim that Schmitt's definitive conceptual position is his concrete order thinking or institutionalism, and not his decisionism of Political Theology. Moreover, they speak in this respect of Schmitt's 'institutional turn,' rather than his 'institutionalist conversion' (p. 25), as this turn did not happen all of a sudden, but can be traced back to Schmitt's writings from 1923.

Croce and Salvatore's book is ordered in three parts, comprising ten chapters in total, and an introduction. The first part of the book is devoted to a critical analysis of the conceptual pillars of Schmitt's 'institutionalist decisionism': normality, law, and collective identity. In the second part of the book, Croce and Salvatore discuss the sources (i.e. 'friends' and 'enemies') from which Schmitt has constructed his institutionalist approach, including Hans Kelsen, Maurice Hauriou, Santi Romano, and Constantino Mortati. These chapters are nicely balanced in that 
they introduce the sources of Schmitt's concrete order thinking while they draw at the same time attention to Schmitt's idiosyncratic use of his sources. In order to vindicate the interpretative work of the first and the second part, in the third and last part of the book Croce and Salvatore develop the issues of legal indeterminacy and legal pluralism, putting Schmitt's institutionalism to the test.

At the outset, Croce and Salvatore explain that they exclusively focus on Schmitt's legal theory (p. 1). They read Schmitt as a legal philosopher, not as a political philosopher. Croce and Salvatore formulate the central problem of Schmitt's legal philosophy as: 'what are the conditions of existence of a stable and effective legal order?' (p. 3) Formulated in this way the central problem of Schmitt's legal thought appears to be about the ground of legal order, indeed, an issue that is central to Schmitt's dispute with Hans Kelsen. What is the ground of 'a stable and effective legal order'? This means that, in Croce and Salvatore's view, Schmitt's concrete order thinking can be interpreted as a critical alternative to normativism. That is, the concept of concrete order is Schmitt's alternative to Kelsen's basic norm. In short, whereas Kelsen presupposes the basic norm as the ground of legal order, assuming normativity (Sollen) and factuality (Sein) to be two distinct realms, Schmitt attempts to integrate these two realms into the concept of concrete order, replacing Kelsen's notion of efficacy with the notion of normality. As Croce and Salvatore note,

'from a normativist point of view, normativity and facticity are two independent realities, which live their own life by and for themselves. (...) According to Schmitt, this understanding of the relation between normativity and social reality is gravely mistaken. Yet, it is not so much for the way rules are conceived. More seriously, this view misconceives social reality and its inner orderliness. Reality, in Schmitt's view, is not mere facticity. It is the domain of normality. (...) Roughly speaking, normality is the way things work in social life when they work properly. No legal norm is able to capture this way. No legal fact-type can encapsulate once and for all a normal conduct in a normal model. Legal norms can only help normality survive and prosper' (p. 35-6).

This is to say that the inner measure of legal order derives from a concretely existing social order, i.e. normal order. As Croce and Salvatore formulate it, concrete order provides the 'social normality' (p. 60) that constitutes the condition of existence of a stable and effective legal order.

Croce and Salvatore's interpretation of Schmitt's legal theory is both provocative and convincing. It is provocative, both from a historical and a conceptual point of view. First, from a historical point of view, the reader meets an author in On the Three Types of Juristic Thought that has just signed his testimony of faith to the Nazi party. Secondly, Croce and Salvatore's interpretation is also provocative from a conceptual point of view in that they claim that in On the Three Types of Juristic Thought Schmitt successfully retakes his much criticized decisionism and develops his concrete order thinking as a cogent alternative. As a matter of fact, 
one of the merits of the book is that it disentangles the conceptual question from its historical framing.

Croce and Salvatore's interpretation of Schmitt's legal theory is, as mentioned, not only provocative but also convincing. Croce and Salvatore argue that in $O n$ the Three Types of Juristic Thought Schmitt attempts to overcome the conceptual impasse between normativism and decisionism by means of developing a third type of juristic thought: institutionalism. In this respect, they speak of Schmitt's 'bumpy road to institutionalism.' To recall, in Political Theology Schmitt developed the decisionist type of legal thinking as an alternative to the normativist type. Whereas normativism presupposes the basic norm as the condition of an effective legal order, Schmitt argued that the normal state of a legal order first needs to be established by a decision. However, decisionism is inadequate because of its 'selffounding logic' (p. 22). In fact, a decision that is 'born from nothingness,' as Schmitt puts it in Political Theology, is as unsatisfying as solution to the ground of legal order as the 'unposited' basic norm.

In order to avoid the normativist and decisionist solution to the ground of legal order, Schmitt '(...) must posit the independent existence of a first and original community, which thus has not been formed by contraposition to any other community' (p. 23). This means that Schmitt is required to reflect on 'the genesis of political unity' (p. 69). That is, he needs 'a theory of the social bond' that allows him 'to reconstruct, explain and account for the process of formation of the internal political unity, regarded as the principle of individualization of political aggregation' (p. 68). It is here that Schmitt's concrete order thinking becomes problematic as he defines political unity substantially. Croce and Salvatore are well aware of the problematic nature of Schmitt's thinking on this point. As they formulate it, Schmitt's '(...) quest for the origins of the political may turn into the politics of the original (...)' (p. 75, italics in original). However, apart from a critical reconstruction, Croce and Salvatore leave the issue of collective identity aside as they focus on Schmitt's legal theory, and not his political thinking. Yet, if Schmitt's notion of political unity is the linchpin of his concrete order thinking, the strict work division between legal and political theorizing is a bit unsatisfactory. For although it is instructive to recognize that Schmitt's legal thought can be placed within a tradition, his version of institutionalism remains nonetheless highly problematic.

Interestingly, the definition of law that follows from Schmitt's institutionalism tends in the opposite direction of what he diagnoses as Kelsen's 'empty formalism.' As Croce and Salvatore formulate it, 'law is both the quintessence and the shelter of a given form of life, as it is meant to crystallize and protect a set of standards and models that are produced by social institutions in everyday life' (p. 158). Actually, the fact that Schmitt's institutionalism is presented as an alternative to normativism, however problematic with respect to some of its assumptions, is a valuable achievement of Croce and Salvatore's book. Moreover, Croce and Salvatore's critical reevaluation of Schmitt's concept of concrete order truly opens up a new perspective on his legal theory that also allows for actualizing Schmitt's thought and reading 'Schmitt against Schmitt,' as demonstrated by the 
Michiel Besters

chapters on legal indeterminacy and legal pluralism. In this respect, Croce and Salvatore's book is recommended reading material not only for Schmitt scholars but also for all those who are in a dialogue with Schmitt, whether publicly or in the seclusion of their study room. 